\title{
An Expanding Culture of Control? The Municipal Administrative Sanctions Act in Belgium
}

\author{
Elke Devroe $^{1}$ (D) Gerben Bruinsma ${ }^{2}$. \\ Tom Vander Beken ${ }^{3}$
}

Published online: 7 July 2016

(C) The Author(s) 2016. This article is published with open access at Springerlink.com

\begin{abstract}
This article provides an in-depth study of the Act on Municipal Administrative Sanctions 1999 (MAS), which is the first major piece of legislation regulating antisocial behaviour in Belgium. MAS provides municipalities with an instrument to sanction antisocial behaviour and conduct perceived to disturb public order. The article uses Garland's (2001) thesis on the culture of control to analyse whether MAS has led to increased government control and the exclusion of significant groups of the population. The research is based on a multiple case study in which the application of MAS was analysed over a 25-year period of security policies in Belgium (1985-2010). The Act's implementation was studied in the two Belgian cities of Antwerp and Liège in order to consider the influence of the Flemish government and the Walloon government, respectively, in this policy area. The article uses insights from this comparison to revisit the culture of control thesis and its limitations in understanding the political competition that exists over the formulation of policies on antisocial behaviour.
\end{abstract}

Keywords Policing public space $\cdot$ Incivilities $\cdot$ Police $\cdot$ Administrative sanctions $\cdot$ Culture of control $\cdot$ Antisocial behaviour

\section{Introduction}

In 1999 Belgium introduced the Act on Municipal Administrative Sanctions (MAS), which enabled municipalities to control antisocial behaviour through the imposition of administrative,

\section{Elke Devroe}

e.devroe@fgga.leidenuniv.nl

1 Institute of Security and Public Affairs, Department of Governance and Global Affairs, Leiden University, Leiden, The Netherlands

2 Netherlands Institute for the Study of Crime and Law Enforcement (NSCR), Amsterdam, The Netherlands

3 Department of Criminology, Criminal Law and Social Law, Ghent University, Gent, Belgium 
rather than criminal, sanctions. To some extent, this framework is comparable to legal initiatives in other countries (see, e.g. Devroe 2012b; Di Ronco and Peršak 2014; Crawford 2008, 2009; De Maillard 2002; Melossi and Selmini 2000; Frevel 2015). This article discusses the origins and development of this approach during the period 1985-2010. The more recent Municipal Administrative Sanctions Act of 2014 is therefore not included within the scope of this research. ${ }^{1}$ In particular, the article considers the political context of the introduction of MAS, its objectives, underlying policy presumptions and moral entrepreneurs. Furthermore, the implementation of MAS is examined in two case studies, namely, the municipalities of Antwerp and Liège.

This article seeks to answer the question: "Can the development of law on antisocial behaviour in Belgium be explained in terms of Garland's culture of control thesis?" Garland's thesis on the sociology of punishment in the Anglo American context, as presented in the book Culture of Control (2001), is used as a starting point for interpreting the origins and subsequent development of policy responses to antisocial behaviour in Belgium, given the influence of this thesis on other accounts of contemporary crime control in Western European countries (Boutellier 2007; Daems 2009; Snacken 2007; Swaaningen 2005). Garland's (2001) work initiated the debate on the relative importance of social forces associated with the onset of late or postmodernity and of local factors in determining penal policy, also framed as the punitive turn (Daems 2008), penal regression (Radzinowicz 1991), pénalisation du social (Mary 1997, 2005), penal temptation (Wacquant 1998, 2004), new punitiveness (Pratt et al. 2005), actuarial justice (Feeley and Simon 1992, 1994) and risk justice and management (Swaaningen 1996).

In this article Garland's thesis is used to draw out the broader questions and themes implied by the introduction of MAS, specifically whether the political imperative for authorities to appear tough and present a punitive display, whilst pursuing more pragmatic measures for managing crime and civil unrest works as an explanation of the origins and subsequent application of MAS. The article therefore outlines the potential significance of Garland's thesis and how it was used to design a multiple case study of the application of MAS in Antwerp and Liège. The results of the case study are then presented, followed by concluding thoughts on the explanatory value and generalizability of Garland's thesis.

\section{David Garland's culture of control}

As this article explores governmental regulation of disorder, Garland's analysis of governmental response to late modern issues of insecurity regarding crime is highly relevant. Central to his culture of control thesis is an analysis of governmental response to disorder and, in particular, the policy predicament. This can be observed as a contradictory mix of measures (see also O'Malley 1999), with on the one hand punitive segregation (control and exclusionary measures) and on the other preventative partnerships and increased informal control by the community. This policy of bifurcation contains no polarization (meaning a sensu stricto governmental response) but a simultaneous performance of contradictory tendencies. Garland identifies the crime-prone society as a main cause of this ambivalent reaction, clustering two basic strategies: the adaptive strategy and the sovereign state strategy. In this context Garland adheres to the fear of crime thesis: the adaptive strategy supposes that the government has to

${ }^{1}$ See: Devroe 2016; Cops and Pleysier 2014; Bauwens et al. 2016. 
adapt to the reality of high crime rates and manage them; the sovereign state strategy denies that the government has lost its grip and constitutes the core of the control theory, with reactions of denial and acting out. Furthermore, he states that the emergence of a culture of control depends on the context of the crime situation and political context, policy assumptions, moral entrepreneurs (advocates, stakeholders) and objectives and criminological theories behind late modern law enforcement. He identifies the loss of penal welfarism in favour of retribution and deterrence as one of the main causes. The welfare mode became more risk prone and offence oriented, and control theories such as the criminologies of everyday life and the criminology of the other began to dominate criminological discourse. Last but not least, the economic style of reasoning and the neoliberal way of thinking are, according to Garland, the main causes of an expanding culture of control. Despite the fact that Garland does not fully expand on the consequences of his thesis for local security governance, his analysis of preventative partnerships is important for framing the empirical results in this article. He places these partnerships within the control framework (Daems 2009) and depicts them as a mix of informal social controls embedded in everyday activities and the interactions of civic society. We conclude this section with five research questions that are addressed in the article:

1. We analysed the social and political context of MAS, the Belgian law on antisocial behaviour. Did MAS originate in a fear of crime, as suggested in Garland's thesis?

2. We focused on the moral entrepreneurs of MAS in Belgium: Were they the professional groups who once dominated the policy-making processes but are increasingly disenfranchised as policy comes to be formulated by political action committees and political advisers (Garland 2001, p. 13)? Was MAS the result of existing ideological and reforming political powers or a product of new institutional arrangements developed as problem-solving devices to deal with "the practical experience of government agencies and their constituencies" (Garland 2001, p. 72)?

3. We studied the policy presumptions underlying the regulation of disorder that could be situated between an expressive/symbolic dimension of the criminology of the other (acting out) or denial - both control dimensions (Garland 2001). Are criminologies of everyday life (rational choice, routine activity or opportunity theories) present in the policy assumptions of Belgian policy makers?

4. We wanted to learn more about the objectives of MAS: Are they the result of a new and urgent emphasis upon the need for security (Garland 2001, p. 13), or are they the result of "modest improvements at the margin, the better management of risks and resources, reduction of the fear of crime, reduction of criminal justice expenditure, greater support for crime victims, more expressive penal measures [that] have become the new policy objectives, as policy analysts deem it more realistic to deal with the effects of crime rather than address the thing itself" (Garland 2001, p. 109)?

5. We wanted to understand the implementation of MAS at the local level and the social reactions of local institutions towards antisocial behaviour: Which different antisocial behaviour measures were taken, and how were they implemented? We sought to analyse Garland's statement that "measures of expulsion and exclusion go hand in hand with the development of a network of preventative partnerships at local levels by patient, ongoing, low-key efforts to build up the internal controls of neighbourhoods and to encourage communities to police themselves" (Garland 2001, p. 17), the latter being an element in the adaptive strategy (Swaaningen 2004). This last question will be answered by analysing the local case studies in Antwerp and Liège. 


\section{Methods and data collection}

The research is a multiple case-study design with triangulation of methods. We wanted to obtain an insight into how and why MAS emerged and was implemented (Orum and Feagin 1991), and a detailed understanding of the institutional political contexts, cultures, historical traditions and governmental arrangements (Newburn et al. 2002). As Belgium has a very specific constitutional/legal setting, it is important to examine general theses about crime control, such as Garland's, with reference to the control policies that apply in the different regions of Belgium [the political specificity of the environment (Mcara 2005)], on the presumption that the politics of this regional, subnational government will help to explain the origins and development of these policies.

Belgium has about 11 million residents, multiple language regions (60\% Flemish speakers, $40 \%$ French speakers and a small proportion of German speakers) and five large municipalities. $^{2}$ Since the state reform of 1970 , Belgium consists of three linguistic regions, 11 provinces, 27 judicial districts and 589 municipalities. As a consequence of the state reform in 1988, Belgium became a federal state. Given this historical evolution of the Belgian federal state and its division into and enmities between Flemish/Dutch-, German- and Frenchspeaking community councils and the regional governments of Flanders, Wallonia and Brussels-Capital, these regional authorities have developed different approaches to local security (Devroe 2013). The Flemish Region consists of 308 municipalities, the BrusselsCapital Region 19 and the Walloon Region 262, each steered by the mayor who directs the (local) police to act in close contact with the citizens and to practise community policing (Devroe 2013). A key consequence of the 1988 federal constitution has been a power shift from national to regional and municipal authorities (Devroe 2013). Only a few policy domains remained exclusively within federal government competence, such as the maintenance of public order (police) and law enforcement (justice). Competencies relating to social policymore specifically, education, employment, health, living conditions, culture, housing, spatial planning - became the responsibility of the regional governments. Because the causes of crime are often situated in regional policy domains, we included regional policy issues in our analysis. Whilst federal and regional authorities retain responsibility for formulating stated goals on security policy, policy implementation (policing in action) (Wodak 2011) became the responsibility of the municipalities (Devroe and Ponsaers 2005). To draw upon a classic distinction between steering and rowing made in the study of governance (Osborne and Gaebler 1993), regional authorities steer social policy responses (policy formulation, e.g. agenda setting, allocation of resources) to quality of life issues; federal authorities steer law enforcement and maintenance of public order; municipal authorities are obliged to row (i.e. implement) both criminal justice and social policy approaches. Consequently, it is at the municipal level that these competing federal and regional responses are negotiated and then executed (Devroe 2015b). In Belgium, the mayor is an independent political figure in each municipality, and Belgian mayors are - like their French counterparts - in charge of and responsible for public order, public peace, security and public health. The mayor can establish general police regulations in his/her municipality and recruit the public police (called administrative police) to determine and record violations. The Communal Act of 30 April $1836^{3}$ created an extensive legislative municipal framework to tackle problems of public disorder

\footnotetext{
${ }^{2}$ Antwerp and Ghent (Flemish speaking), Charleroi and Liège (French speaking), and Brussels (both languages).

${ }^{3}$ Renewed by the New Communal Law (Nieuwe Gemeentewet), B.S., 3 September 1988.
} 
under the patronage of the federal government. It is important to mention here that from 1991 until 2014 the Socialist Party ruled in a federal coalition. In the period covering MAS's genesis (1988-1999), all ministers of interior (federal), municipalities (federal) and cities in Flanders and Wallonia (regional ministers) were socialists.

Data processing for this study was oriented around two main topics: (1) the genesis and (2) the implementation of MAS. In case study A, the genesis was analysed at a federal level over a 25-year period (1985-2010). Data collection was organized around the five research questions (supra). Political reactions to increasing problems of urban antisocial behaviour were analysed in a broader historical context of social and governmental changes in security policy over the study period. This historical reconstruction involved 26 semistructured face-to-face interviews ${ }^{4}$ (Fontana and Frey 1994), with experts (Aberbach and Rockman 2002) from different policy levels. All ministers of interior and justice who served during the research period were interviewed. In 1999, during the presidency of Prime Minister Verhofstadt I, the position of Government Commissioner of Metropolises was introduced. In 2000 this function was transformed into the Minister of Metropolises, which was installed to steer and finance renovation and social cohesion projects in the five major cities in Belgium. These successive ministers were also interviewed, along with representatives of their cabinets, members of parliament, political advisors, governors and civil servants. We gathered significant information on how the perceptions of these policy experts led to certain policy assumptions, motivations, basic principles, statements and, finally, actions. We chose a semistructured style of interviewing in order to gather a diversity of significant answers at a sophisticated level.

In addition to interviews, an extensive document analysis ${ }^{5}(\mathrm{~N}: 432)$ of official and confidential policy documents was carried out. Analysis included governmental programmes and policy plans; national and local security plans; reports of the Council of Ministers; the Cabinet of the Ministers of the Interior, Justice and Metropolises; statistical reports; annual reports; elective programmes; reports and informal notes of regional councils; preparative documents for Acts; personal letters between ministers; and so on. Thanks to ministers' and cabinet members' assistance, we were able to gather exclusive, confidential ${ }^{6}$ political material that had not been revealed before (e.g. minutes of meetings in parliamentary committees, informal and formal letters between ministers, minutes of intercabinet meetings).

In order to study the implementation processes of the federal MAS and possible diverging policy instructions from regions at the metropolitan level, two nested case studies (based on differences) in Antwerp (Flemish speaking) (case study B) and Liège (French speaking) (case study C) were added to the analysis. Both cities implemented MAS in 2005, so the relevant period for an analysis of the uses of MAS in these cities is 2005-2012. We chose these particular cities in order to identify any intraregional differences originating in linguistic political influences on the one hand (both cities' political representatives are currently left wing, but $25 \%$ of voters chose the extreme right-wing party Vlaams Blok in Antwerp in 1991; voters in Liège have consistently voted for left-wing representatives) and political culture (Flemish or Walloon) on the other.

Although the population size of Antwerp and Liège varies greatly, they both face a massive inflow of commuters (work and tourism) on a daily basis. In both cases, we focused on policy

\footnotetext{
${ }^{4}$ All interviews were completely transcribed, and the 72 interviews have been kept on tape in archives. A list of names of all respondents and their functions has been published (Devroe 2012a). A selection of quotes from the interviewees is used in this article.

${ }^{5}$ A list of the documents has been published (Devroe 2012a), and all documents used are stored in archives.

6 This information was used in the analysis, and the source was referred to as "confidential document'.
} 
makers from the particular institutions responsible for shaping and conceptualizing antisocial behaviour strategies and civil servants who are responsible for implementation of MAS. This approach led us to actors in prevention and social welfare and to institutions of law enforcement (police, justice). In each city, we held 23 face-to-face interviews ${ }^{7}$ (in Dutch in Antwerp; in French in Liège) with mayors, public prosecutors, police constables and chief commissioners, social workers, wardens in public transport, city units responsible for the prosecution and sanctioning of antisocial behaviour, members of the local council (college of alderman), city wardens, city coachers, mediators, street-based social workers, those piloting neighbourhood projects, etc. These interviews were complemented with an extensive document analysis for each city, including municipal statistics on antisocial behaviour, policy plans of majors, local security plans, police plans, antisocial behaviour plans, minutes of the city council, activity reports of institutions, reports of city wardens, and so on.

\section{Results}

\section{MAS genesis}

Regarding the social and political context of MAS (question 1), most respondents referred to various events and scandals that shook Belgium's political institutions and challenged their authority to cope with issues of crime and safety in the late 1980s. The 1980s were described as a black page in Belgian history, marked by the extremely violent raids and killings by the Nivelles Gang (Dupont and Ponsaers 1988), terrorist attacks by the communist Cellules Communistes Combattantes and the deaths of 39 football supporters at the 1985 European Cup Final in the Heysel Stadium. In addition to those events, many other incidents during that period cast a shadow over police and the justice system. Respondents also noted a growing concern about the influx of migrants in the larger cities, a rapidly changing demographic situation in the capital cities and the political success of the extreme rightwing party (Vlaams Blok) in Flanders. On 24 November, 1991, Vlaams Blok obtained $6.6 \%$ of the votes, or 12 of 212 seats in Parliament. This day is now referred to as Black Sunday, a day on which more than 100,000 voters formally expressed their lack of trust in the existing political system (Huyse 1996). Considered a state legitimacy problem, this electoral shift stimulated political awareness of problems of social disorder and minor crimes in deprived neighbourhoods (Van Limbergen 1995). The last wave of incidents occurred in the mid to late 1990s with the 1996 arrest of Marc Dutroux, a paedophile who imprisoned and murdered children. His arrest was accompanied by a massive public expression of solidarity with the children's parents. The White Balloon March in Brussels in 1996, attended by 300,000 people, was a public statement against the incompetence of police and the justice system. In April 1998 Dutroux briefly escaped during a prison transfer, leading to moral panic in the country and resulting in the unavoidable resignation of the Ministers of Interior and Justice. According to many respondents, the police reform that was quickly voted in after this escape ${ }^{8}$ was considered by all political parties to be necessary to the recovery of governmental legitimacy.

\footnotetext{
${ }^{7}$ All interviews were completely transcribed and kept in the archives. Names of respondents and a list of all documents used in the analysis have been published (Devroe 2012a).

${ }^{8}$ Called the "Octopus agreement' because suddenly the eight political parties all agreed on the Police Reform Act (7 December 1998, B.S. 5 January, 1999).
} 
A second stimulus for MAS's genesis was the state reform of 1988 (supra). Following this reform, the Minister of Interior, Louis Tobback, called the Cabinet of the Interior "the preservation room for grumpy old men with nothing more to decide." The election programme of the Socialist Party ${ }^{9}$ showed, following state reform, that socialist politicians did not want to be constrained by the party's very narrow range of policies, which stressed repression and public order. They expressed a strong belief in the need for tailor-made support for major municipal areas, and wanted to formulate and implement new policy measures that tackled the causes of crime, even though such tasks had, since 1998, been allocated to the regions and so were officially outside their political sphere. Furthermore, the electoral shift to the extreme right led to a political awareness among socialists that something had to be done to equip cities with the right tools to tackle the deterioration and collapse of social cohesion. Prevention measures (situational, but also social) became key strategies in tackling crime and feelings of insecurity. The federal government financed many social projects, including drug rehabilitation programmes, situational prevention projects such as street cleaning and litter removal, neighbourhood centres and street-based social workers. Policy makers at that time were convinced that punitive answers to minor crimes could only exacerbate the issues at hand (De Witte 1988). Political assumptions were closer to those of the Broken Windows theory (Wilson and Kelling 1989), transforming cities in attractive and clean places, than to deterrence and punishment that was oriented towards individuals (mostly young people), as had been the case after the murder of Jamie Bulger in the UK. Belgian laws were not obviously directed at offensive behaviour (especially by young people), which has featured so significantly in policy in the UK. Because antisocial behaviour is legally considered to be a part of public order problems, the debate on antisocial behaviour that characterized UK debates was not seen in Belgian political debates. The Belgian law is called Municipal Administratrive Sanctions, which reflects its focus on public nuisances (trespass, mess/litter, environmental harms - with the mayor being responsible for maintaining health, peace and order in the city) rather than possessing the almost subcriminal character that antisocial behaviour laws have acquired in the UK (Devroe 2016).

Document analysis and interviews clearly reveal that socialists' reactions to police and judicial malaise was inspired by the French politician Bonnemaison, ${ }^{10}$ to take a preventative approach. The federal government approved of the intentions of Louis Tobback, ${ }^{11}$ transcribed in the ministerial declaration "Security of the citizen, police and security" of June 1992. One of the main propositions in this document was extensive funding for crime prevention ${ }^{12}$ (Glorie 1997, 2004; Willekens 2008). In order to get a new grip on city governance after the state reform, city contracting (like in France; see Roché 2005), was installed. After consulting the five mayors of the major cities (all socialists) about the amount of federal funding, so-called prevention contracts were signed between the Minister of the Interior and those mayors. The investment consisted mainly of personnel: prevention workers were installed who introduced

\footnotetext{
${ }^{9}$ De Witte (1988) 'Security and petty crime' (Veiligheid en kleine criminaliteit), an electoral document for the municipal elections.

${ }^{10}$ A 1982 report Face a la délinquence, prévention, répression, solidarité, written by Gilbert Bonnemaison and 26 municipal mayors, explored crime in metropolitan areas and prevention measures for young people. This report led to the establishment of prevention councils and prevention contracts in France and was the example for the Belgian prevention policy contracts.

${ }^{11}$ Minister of the Interior at that time.

12 Directive of the Minister of the Interior of 12 November 1990 to the mayors on the prevention of crime, and Directive of the Minister of the Interior of 30 November 1990 to the mayors on the security and prevention contracts.
} 
unemployed, low-skilled citizens into entry-level jobs, such as football coaches, stewards, city monitors, park guards, parking-lot guards and other prevention personnel. This was the first occurrence of a cohort of civil surveillance wardens in public spaces executing tasks such as warning, helping citizens with enquiries and noting down complaints about public infrastructure (Devroe 2015a). As most of these workers were located in the same building as the public police housed within police offices, some were-like the public police - employees of the local authority. One year prior to voting on MAS in 1998, a total of 123 million euro was invested in the cities, installing a fragmented body of surveillance wardens on public streets and squares, helping police to keep peace and order. In 2000, the Minister of Metropolises (also socialist) followed his colleague at the interior and invested a significant amount of funding in the five largest cities, more specifically in social cohesion projects, ${ }^{13}$ resulting in an increasing body of social workers such as street-based workers and mediators in public spaces. Confidential letters between Ministers of the Interior and of Metropolises ${ }^{14}$ indicate that the positioning of civil wardens in public spaces - an important aspect of the prevention contracts - was the essence of what would become MAS the year after. This clearly illustrates the fact that MAS originated as a preventative and not a criminal law enforcement measure (as had the Antisocial Behaviour Orders (ASBOs) in the UK; Matthews et al. 2007; Field 2003). We specify this last statement in the answers to our second and third queries - namely, moral entrepreneurs, policy assumptions and MAS objectives - which we analyse in the following paragraphs.

Analysis of the extensive body of policy documents dating from the crucial period before the voting for MAS (1999-2005) and the interviews leads to the conclusion that the socialist body of thought (the belief in the feasibility of society, in state engineering) was transferred across key positions, governmental levels (federal and regional) and even across linguistic tensions. ${ }^{15}$ The in-depth political reconstruction of communication between different stakeholders shows that the sole moral entrepreneurs were the socialists (politicians and cabinet members), installing MAS as a last resort following the preventive financial injection that political party officials had implemented from the early 1990s onwards. Their main objective was to install formal and informal surveillance in public spaces in order to address public feelings of insecurity and to establish what could be called a city code of conduct by implementing MAS.

There were no theoretical assumptions (our third question) underlying this decision: the approach to antisocial behaviour arose from the pragmatic experience of politicians, called a rational-within-limits view (Garland 2004). Only the Minister of Metropolises asserted that he had analysed a number of French scientific studies on urban crime problems, such as Bonnemaison. Though the installation of a body of civil city wardens could refer to capable guardianship (Felson 2002) and so fit in the opportunity theory, the MAS approach could not be called a demoralizing effect of situational crime prevention where the new approach does

\footnotetext{
${ }^{13}$ Act of 17 July 2000 on the requirements municipal authorities have to meet in order to get funding stipulated in contracts with the Ministry of Metropolises, B.S. 8 August 2000.

14 The Department of Metropolises was socialist for the entire period, from its establishment in 1999 until 2008 (Ch. Piqué, J. Vande Lanotte: 1999-2003, M. Arena: 2003-2004 and Ch. Dupont 2004-2008).

${ }^{15}$ To give a concrete example, when the Socialist Party no longer occupied the position of Minister of Interior, the socialist (French) Minister of Justice (from 2003-2007) became - together with the Flemish socialist Minister of Finance and the French Minister of Metropolises - moral entrepreneurs for the successive MAS Acts of 2004 2005 .
} 
not look to the revival of social controls and self-controls. Instead, it seeks to make a new style of 'situational engineering' succeed where 'social engineering' failed"' (Garland 1997, p. 189).

The objectives (question 4) of MAS were - after 10 years of federal investment in crime prevention and a penal system that completely ignored sanctioning municipal violations - to counteract impunity by providing municipalities with a legal instrument to sanction incivilities. By broadening city council competences to sanctioning, municipalities were put in control of the entire chain of enforcement policy: establish regulations, prosecute and punish (Van Heddeghem 2006). As the Flemish government had competence over sanctions and justice but wanted to decrease crime and disorder, the Flemish Minister of Cities (socialist) also invested in contracting (Social Impulse Funding, Sociaal Impulsfonds) in order to install social policies of city renovation and social cohesion projects in exchange for (Flemish) funding. The following quote illustrates the intention:

As we had no competences on problems of crime, and we wanted to reorganize crimeprone cities into viable, agreeable spaces, we tried to invest in citizens' participation. Of course this was done to avoid a conflict between our official (narrow) competencies and our own policy goals. This Flemish money was only meant for the so-called deprived neighbourhoods. So you were obliged to work in certain bad neighbourhoods, which were overpopulated, with a great mix of cultures and a lot of integration problems and sociodemographically and economically floating beneath the societal surface. And those you have to renovate, so you organize a competition to find out what people think it is important to have in public space (civil servant of the Flemish cabinet).

In 2003, almost 7 years after the Flemish investments, Wallonia ${ }^{16}$ was also able to provide funding for Walloon cities following the signing of contracts between the cities and the Walloon executive that guaranteed the use of prevention-based approaches. This gave a great boost to Flanders, providing infrastructure improvements that were supported by local citizens, and contributed to a reduction in feelings of insecurity (Devroe 2012b). Therefore, if MAS is viewed in isolation, its objectives can be considered to be "modest improvements at the margin, the better management of risks and resources, reduction of the fear of crime, reduction of criminal justice expenditure, greater support for crime's victims" (Garland 2001, p. 109). We now elaborate on MAS itself.

\section{Regulating antisocial behaviour: MAS}

Tackling antisocial behaviour is a municipal matter in Belgium, directed by the mayor and executed by the public police. This practice, together with the strict division between administrative (public order) and judicial police, is particular to the Belgian constitutional setting stemming from a history of local autonomy (Devroe and Ponsaers 2013). MAS ${ }^{17}$ provides local councils with an appropriate instrument enabling them to swiftly and forcefully tackle antisocial behaviour on municipal land. As the Belgian legislator considers antisocial behaviour to be an element of disturbing public order, MAS was embedded in the existing Municipal Act of 1999, creating three innovations: (1) the ability to close down establishments and

\footnotetext{
${ }^{16}$ Decree of the Walloon Government of 15 May 2003 on prevention and proximity in cities and communes in Wallonia, Ministerial Decision, 4 February 2004: 6701.

17 Act of 13 May 1999 on Municipal Administrative Sanctions, B.S. 10 June 1999.
} 
suspend licences, (2) enlargement of the notion of public order to antisocial behaviour ${ }^{18}$ and (3) competence for the mayor and alderman to sanction (with fines up to 340 euro) infringements of municipal regulations. MAS combines administrative measures (briefly, measures taken by the mayor, such as closing down bars and discotheques, withdrawal of licences, issuing fines) and administrative sanctions imposed by the city council (mainly fines). Before the amendment in 2004, municipal authorities could only react to the types of behaviour for which neither the federal nor the regional parliament has provided penalties. In other words, municipalities could only respond to new types of antisocial behaviour that had not already been addressed by existing legislation. ${ }^{19}$ In practical terms, local administrative sanction legislation proved to be an "empty barrel" for municipalities. As any overlap with existing provisions elsewhere was formally excluded, local councils did not have much room to manoeuvre (Vander Beken and Vandeviver 2014). Moreover, the Act of 1999 allowed municipalities to draft their own laws but not to appoint designated enforcement staff. Antisocial behaviour could only be established by a report made by police (Devroe 2008). Before MAS, sanctioning antisocial behaviour was the responsibility of the judicial authority (police courts), creating considerable congestion in the public prosecutor's daily workload. For political reasons - namely the belief in tailor-made local governance with a strong emphasis on municipal autonomy-MAS was meticulously amended by the federal parliament in 2004, leading to two new acts in 2004. In the preparation of this act we noticed - for the first time - a strong voice (Minister of Justice L. Onkelinx, also socialist) underlining the need for mandatory mediation before punishment. These acts treat minors (aged 16-17) as eligible for sanctioning using MAS, but only after mandatory mediation (Vander Beken 2005).

This revised act combines administrative sanctions with criminal procedures in a particular way. In order to hand over sanctioning competencies to the municipality, a series of violations were depenalized. These violations were no longer delimited by other legislation and could be integrated into municipal procedures. A second group of criminal offences are referred to as mixed violations, i.e. behaviour that qualifies as both a criminal offence and an offence written down in municipal regulations. These are not depenalized, but the municipal council is at liberty to issue a pecuniary fine of up to 250 euro for these offences in its byelaws, as the existing penalties provided under the penal code remain untouched when the public prosecutor decides to pursue a case.

The penalties already included in the penal code are in turn divided into two separate procedural settlements in which the official police report is required to be sent to the public prosecutor's office in all cases. With regard to the first series of criminal offences (the so-called lighter-mixed violations), administrative pecuniary fines can only be imposed when the public prosecutor does not communicate his position in the case to the civil servant within 1 month of receiving the police report. If the public prosecutor has allowed this term to expire without making his or her position known, offences under this first series of criminal offences can only and exclusively be punished administratively, with the local council at liberty to take up the prosecution of this offence. Of course, an individual cannot be punished twice for the same offence (non bis in idem). ${ }^{20}$

\footnotetext{
18 Art. 135 par. 2 al 7 MAS.

${ }^{19}$ This means not only federal legislation but also regional decrees on environmental issues, town and country planning, construction companies, residential inspection, etc.

${ }^{20}$ Parliament, Chamber 1, 2002-2003, number 2366/1 and 2367/1, 3-5.
} 
The second series of criminal offences (the so-called more serious mixed violations) results in penalisation under traditional criminal justice, unless the public prosecutor's office indicates that it would be more appropriate to impose a pecuniary fine. With regard to this series of criminal offences, the municipal civil servant can only impose an administrative pecuniary fine if the public prosecutor has advised him/her within a preset timespan that the violation shall not be pursued any further and that he/she feels it would be appropriate to impose an administrative penalty. If the public prosecutor fails to communicate his/her position, and the provided time period has expired, the local council is no longer at liberty to act in an administrative sense, which means the violation must be settled in a criminal justice context. It is up to each municipality to draft a list of violations that are punishable by MAS. The 2005 revision of the $\mathrm{act}^{21}$ made it possible for municipal officers to draft reports and sanction all municipalities' regulations, in addition to the public police.

\section{MAS implementation in two cities}

Regarding the fifth research question on the mix of informal social controls embedded in the everyday activities within preventive partnerships at local levels, analysis of 46 interviews and numerous documents led to some specific results. Questions such as: "What are the rules of discourse and action that organise the diverse practices that made up this field?" "How are these rules and these practices related to those of other social domains, such as welfare, politics or the economy?" "What role do these practices play in the governance of late modern society?" (Garland 2001, p. 2) were analysed in both cities. The way in which MAS was implemented was reviewed - whether top down, meaning mandatory as imposed by city hall, or bottom up, originating in small initiatives within civic society. During the empirical search, attention was paid to the ways of thinking that underlie the programs (mentalities), the organisational forms used to implement those ways of thinking (institutions), the techniques used to turn mentalities into action (technologies) and, of course, results (practices) (Johnston and Shearing 2003, p. 13). Results show a great variety in both cities.

In Antwerp, we noticed a very enthusiastic and immediate application of MAS, welcomed by city hall as an excellent opportunity to govern the city, with extra tools for the mayor to execute local security policy. Wardens were able to initiate antisocial behaviour reports, and the administrative staff had the authority to sanction. The local police code was completely overhauled, with administrative sanctions for many minor offences ranging from traffic offences; to antisocial violations at markets, restaurants, bars and sports events; to begging and drinking in public spaces; and hanging out, insulting and intimidating others. Under the socialist mayor P. Janssens, a special city department called Living Together was created, which initiated surveillance and control, street-based social work and educational programmes. The whole security chain, from prevention to mediation, to prosecution and sanctioning, was coordinated by one director in what was called an integrated approach. As had been found when assessing the objectives question, socialist ministers intended to treat MAS as a final option after preventive measures; handing out fines was seen as a final stage when prevention approaches had failed. Mediation is in place for young people. According to the mayor of Antwerp, the director of the Living Together department and civil servants working in city hall, the aim of mediation is to change the attitudes and conduct of young people who exhibit

${ }^{21}$ Act dated 20 July 2005 establishing various provisions - matters pertaining to the civil service and urban policy_municipal administrative penalties (art. 21-22), B.L.G, 29 July 2005. 
antisocial behaviour by providing a variety of programmes and services (educational, aggression management, sports facilities, assistance at school, etc.) in order to avoid sanctions (fines). Some respondents saw this as a positive early intervention; others saw it as subjecting the young people to intrusive control in the name of diversion or prevention, forcing them into welfare. In Antwerp, young people who are following the programme in order to avoid sanctions may be subject to net-widening effects, because what was considered normal adolescent behaviour of short duration before MAS is now labelled as a problem that requires special attention and care, and-if a young person does not complete a prevention programme - is regarded as worthy of a fine.

Antwerp uses the bargaining model of contracting that is widely used in Anglo Saxon countries, showing characteristics of a multiagency approach with fixed horizontal networks. The preventative partnerships are a core aspect of antisocial behaviour governance, linking actors from different backgrounds and policy domains in one network, and considering the creation of personal dossiers of young offenders to be a policy priority for the whole city. These networks are not mandatory in the way that Crime and Disorder Reduction Partnerships are in the UK (Edwards and Prins 2014) but can be understood within a broader tendency towards horizontal security governance instead of top-down government.

In Liège we found a completely different interpretation of MAS. As policy decisions there are based on the Canadian approach, there is a fundamental belief in the importance of highprofile community-oriented policemen. City wardens cannot issue fines; they only assist the police in monitoring signs of disorder. The policy assumption is that that there is no need to create a kind of municipal criminal justice system when a transparent legal justice system is already in place. In the view of the mayor, the chief of police and many other experts responsible for public order and antisocial behaviour, warnings (oral or written) from the police are the best remedy against frequent disorder, and there is no need for extra fines. Therefore, the Liège municipal regulation code remained limited to violations at specific markets, festivities and sports events. Mayoral measures (see above) are not included in the code and cannot be executed, nor are exclusion measures such as street bans or night curfews. According to respondents, too many prohibitions would hinder inhabitants and restrict their privacy. Analyses showed a total rejection of the use of mediation as a tool to avoid fines. Once a case is registered and proven, a fine is given, even after (successful) mediation. In comparison with Antwerp, the act of 1999 is rarely applied, the police code was not substantially revised, and punishment of antisocial behaviour by the classic law enforcement agencies of police and justice continued as before.

Liège City Hall carries out specific projects (e.g. street cleaning, targeted alcohol control, free bus passes) and connects actors on an occasional basis for a more integrated approach. These connections, however, are not integrated into a specific framework and often dissolve following the project. Collaboration is based on the initiative and willingness of participants, as there are no official agreements. Tasks related to welfare and social cohesion (completed by social workers) are clearly distinguished from tasks involving prevention and sanctioning (executed by police and justice). Both cities illustrate a bottom-up approach, initiated from a small number of ideas that took shape and were formed in a later phase, confirming Garland's statement that "They subsequently became de facto strategies attracting widespread support and multiple ex post facto rationales, the plan followed the practice rather than the other way around" (Garland 2001, p. 105).

It is clear from this study that Antwerp implemented MAS wholeheartedly and within the broader objectives of an integrated security policy. In both of the two case studies, local 
politics was effective in implementing policies in ways that the federal government intended. In Antwerp, MAS is an important instrument, but only as the last part of an integral local policy chain. Liège was more reluctant to implement MAS, and only uses instruments that are already available in the criminal law enforcement system to regulate antisocial behaviour. Liège mostly invests in social welfare and prevention approaches instead of issuing fines.

\section{Conclusion and discussion}

As difficult as a comparison and the translation of criminological concepts can be (Edwards and Hughes 2013; Edwards et al. 2013; Nelken 2015), our research shows the importance of empirical research on control theories in different contexts and on different phenomena. In this article we broadened Garland's insights on a phenomenon that he did not analyse empirically - namely, issues of public order in public space. As this space became scarce (Hope 2000) the quality of life discourse gained importance (Crawford 1999, 2001; Edwards and Hughes 2002), putting the regulation of disorder in the political spotlight. The Crime and Disorder Act in the UK, regulating public behaviour and mostly targeting individuals who disturb public order, was introduced (1998) before the culture of control (Garland 2001) came about. The Criminal Justice and Public Order Act (1994), introduced by Michael Howard (Home Secretary under a Tory government) aimed to criminalise individuals with an unconventional lifestyle, such as gypsies, squatters and ravers (Hughes 2007); the 1994 New Labour policy plan "A Quiet Life: Tough Action on Criminal Neighbours" (Squires and Stephen 2005) tempted us to broaden Garland's insights into this public order domain by piloting extensive empirical research with more than 400 policy documents and 72 in-depth expert interviews. Regulating public space is an important task of mayors in most Western countries and can lead to exclusionary mechanisms (Young 2007, 2009). A digression on this important semiautonomous field (Bourdieux) of control in public space in Garland's culture of control would have been valuable, even more so since stringent modes of control in this area were already installed in the UK before the publication of his book in 2001.

Applying Anglo Saxon penal insights to the continental setting of a civil-law (federal) country with a complex constitutional setting was a challenging enterprise. We believe this multiple case study research design was justified in relation to the proposition that politics matters (Stone 2008) in explaining the origins and development of control strategies; and in Belgium, that implies a concern with the contrasting politics found in the different regional governments as a consequence of the Belgian constitutional/legal settlement. The detailed reconstruction of the genesis of MAS and of, more generally, Belgian security policy from 1985 to 2010, broadened the scope of classic criminological research (Bruinsma and Huisman 2006) (which, when analysing national acts, usually focuses exclusively on the enforcement of criminal law measures that have been set out by ministers of the interior and of justice). The link with fragmented regional and local competences due to federalisation processes when studying a national act is rarely made: as Hamilton (2014) put it when discussing the fact that research has examined institutional arrangements, national culture and the interaction between the two, the impact of a jurisdiction's political culture on penal policy has remained a largely underexamined topic. Prohibiting government officials in charge of police and justice from creating social approaches such as restorative justice and social prevention (state reform) sheds light on the intentions of governmental state actors. As we did not limit ourselves to the police senso stricto approach (the act installed by the federal government) but studied the political 
dynamics between federal, regional and local actors in the common "policing goal of making cities clean, liveable and attractive again, the detailed reconstruction revealed some very unexpected results.

First, we found a coherent rationale among those who create and implement policy that is, to a certain degree, contrary to Garland's thesis, which emphasises volatility and ambivalence (see also O'Malley 1999); and the regulation of antisocial behaviour was strongly influenced by the ideological body of thought of Socialist Party officials (French and Dutch speaking) who shared a strong belief in social prevention and, as an ultimum remedium if prevention and warnings fail, a local tailor-made instrument in the hands of the city council to sanction frequent antisocial behaviour. We believe this socialist ideology to be the main element of resistance against purely punitive reactions in the Belgian political context.

In Belgium, there was a lack of confidence in crime-fighting models and criminal law enforcement approaches, such as the UK's ASBOs and Criminal ASBOs (CRASBOs) (Bottoms 2006; Burney 2005; Card and Ward 2008) or Australian control orders (Zedner 2007) in the period covered by this research, with the socialists calling instead for an approach that would lead to a better quality of life in a preventative manner. As one of the causes of MAS was the flight to the extreme right in 1991 and the complete absence of justice in the regulation of minor crimes that citizens complained about, it is obvious that socialists wanted their electorate back, which they managed to do for 12 years in federal government. The two case studies (Antwerp and Liège) retained socialist mayors from 1976 until 2013, when a right-wing mayor took over the mayoral sash in Antwerp (but not in Liège). By ignoring minor offences and antisocial behaviour that disrupted people's lives, fears of a second extreme right electoral turn became a reality.

To conclude: local politics do matter. Our results elucidate the second factor in Garland's analysis, the local factors determining control policy more than they do the importance of social forces associated with the onset of late modernity. Socialist mayors sitting in parliament from all five major cities in Belgium shaped the intentions, the assumptions and the objectives of MAS, together with their Socialist Party members at a federal level and at both regional levels. As this act is a nonmandatory instrument that is available for all mayors in their task of keeping peace and order, it is to be expected that politics will be an important factor. Although the act sets structural legal limitations not to punish behaviour that is already penalised in a federal or regional act, net widening can be a dangerous side-effect of this act, broadening the control perspective. Although our empirical observations explicitly showed no reason to believe that risk assessment and control measures were the intention of the original (socialist) moral entrepreneurs, local mayors can decide otherwise. As the Socialist Party had completely vanished in federal coalition and in Antwerp, right-wing and conservative parties demonstrated diverging policy agendas and were able to implement diverging strategies. Recently, Belgian austerity policy has led to huge budget cuts, specifically in social insurance and other programmes of social care, welfare and prevention. Disconnecting local (sanctioning) policies from local preventative and welfare policies could turn MAS practices into a purely repressive and punitive arrangement.

Second, Belgian socialist officials do not comply with regulations for state reform, which is only possible in the typical Belgian political-bargaining consensus model of governance. Our analysis showed that although the Minister of the Interior (an empty barrel) formerly had no say over municipalities and certainly not in the domain of social prevention (only in terms of repression), in fact, the minister found a way to govern municipalities from a distance by "contracting politics, so imposing on them a preventative and welfare-oriented ideology. This 
was not, as in the UK, about creating networks. In fact, the minister found a way to govern municipalities from a distance by using a community safety approach, so imposing on them to create crime prevention networks ${ }^{22}$ As prevention officers were mostly located in police stations, it was more about transferring processes of social justice and prevention to a tailormade level: cities. This rather unusual approach, which is due to Belgium's complex constitutional setting, touches on Lijphart's (1999) distinction between consensus and majoritarian democracy as a key element in explaining the country's moderate model of regulating antisocial behaviour.

In conclusion, it can be observed that MAS offers municipalities a tool to steer local problems by providing administrative fines and is accompanied by tailor-made prevention programmes that are not oriented towards a dangerous other but are relevant to all municipal inhabitants. MAS cannot be called an expressive/symbolic dimension of criminology of the other (acting out) or as an illustration of a stronger repressive governmental grip. Our results are in line with the findings of Goddard (2012), who supports the development of a thesis that prevention and welfarist traditions survived the transition to late-modern risk-management developments, at least in policy intentions at the federal level, and in Liège. Our analysis has shown that the culture of the control framework contains elements that help explain and understand the emergence and application of MAS. It is clear, however, that not all aspects of regulating antisocial in Belgium fit within Garland's limited scope of the sociology of punishment. Complementing Garland's thesis with theoretical and empirical insights into public order issues in general and on regulating public space in particular would enlarge our understanding of control theories in late-modern society. How can we explain convergent or divergent regulating tools and practices between different metropolises embedded in the same nation state? Can we detect more explanatory variables than historical evolutions, linguistic characteristics and political ideologies? This last question illustrates the need for further research and confirms the culture of control thesis as a useful framework for analysis. However, Garland's insights do not necessarily have an explanatory value in the empirical study of public order and antisocial behaviour at the local level.

Open Access This article is distributed under the terms of the Creative Commons Attribution 4.0 International License (http://creativecommons.org/licenses/by/4.0/), which permits unrestricted use, distribution, and reproduction in any medium, provided you give appropriate credit to the original author(s) and the source, provide a link to the Creative Commons license, and indicate if changes were made.

\section{References}

Aberbach, J. D., \& Rockman, B. A. (2002). Conducting and coding elite interviews'. Political Science and Politics, 35(4), 673-6.

Bauwens, T., Pleysier, S., De Pauw, E., \& Van Den Broeck, T. (Eds.). (2016). De nieuwe GAS-wet: zuurstof of stikstof?', Orde van de Dag. Diegem: Kluwer.

Bottoms, A. (2006). Incivilities, offence, and social order in the residential communities'. In A. Von Hirsch \& A. P. Simester (Eds.), Incivilities: Regulating Offensive Behaviour - Studies in Penal Theory and Penal Ethics (pp. 239-81). Oregan: Hart Publishing.

Boutellier, H. (2007). Nodale orde: veiligheid en burgerschap in een netwerksamenleving. oratie VU. Amsterdam, $53 \mathrm{p}$.

Bruinsma, G.J.N. \& Huisman, W. (2006). Over de grenzen van de klassieke criminologie. Een beschouwing over nieuwe kennisvragen door de incorporatie van onveiligheid als object in de criminologie, in W. Huisman,

$\overline{22}$ The first governmental white paper on the integral security ideology dates from 2004. 
L.M. Moerings \& G. Suurmond (eds), Veiligheid en Recht. Nieuwe Doelwitten en Strategieën (pp. 269-95), Den Haag: Boom Juridische Uitgevers.

Burney, E. (2005). Making People Behave: Anti-Social Behaviour. Politics and Policy, Uffculme: Willan Publishing.

Card, R., \& Ward, R. (2008). The Crime and Disorder Act 1998: A Practitioner's Guide. Bristol: Jordans.

Cops, D., \& Pleysier, S. (2014). De wet op de gemeentelijke administratieve sancties: een korte introductie. Agora, Tijdschrift jongerenbegeleiding, 30(1), 30-3.

Crawford, A. (1999). Questioning appeals to the community within crime prevention and control'. European Journal on Criminal Policy and Research, 7(4), 509-30.

Crawford, A. (2001). Les politiques locale de prévention de la délinquance en Angleterre et au Pays de Galles'. Déviance et Société, 25(4), 427-58.

Crawford, A. (2008). Dispersal powers and the symbolic role of anti-social behaviour legislation'. The Modern Law Review, 71(5), 753-84.

Crawford, A. (2009). Governing through anti-social behaviour: Regulatory challenges to criminal justice'. British Journal of Criminology, 49, 810-31.

Daems, T. (2008). Making Sense of Penal Change, Clarendon Studies in Criminology. Oxford: Oxford University Press.

Daems, T. (2009). De bestraffingssociologie van David W. Garland, Den Haag: Boom Juridische uitgevers.

De Maillard, J. (2002). Les nouvelles politiques socio-urbaines contractuelles entre conflits et apprentissages. Politix, 15(60), 169-91.

De Witte, L. (1988). Veiligheid en Kleine Criminaliteit (pp. 1-238). Campagne Socialistische Partij, gemeenteraadsverkiezingen 9 Oktober 1988, SEVI publicatie (studiegroep van de partij).

Devroe, E. (2008). 'The policy approach of nuisance problems in public space in Belgium and the Netherlands. In L. Cachet, S. De Kimpe, P. Ponsaers, \& A. Ringeling (Eds.), Governance of Security in the Netherlands and Belgium (pp. 149-75). The Hague: Boom Legal Publishers/Eleven.

Devroe, E. (2012). A Swelling Culture of Control. De Genese en de Toepassing van de Wet op de Administratieve Sancties in België, Antwerpen/Apeldoorn: Maklu, 529 p.

Devroe, E. (2012b). A swelling culture of control: The genesis and application of the incivilities law in Belgium. In P. Ponsaers (Ed.), Social Analysis of Security: Financial, Economic and Ecological Crime, Crime (In)security and Distrust, Public and Private Policing (pp. 355-62). The Hague: Eleven International Publishing.

Devroe, E. (2013). Local political leadership and the governance of urban security in Belgium and the Netherlands'. European Journal of Criminology, 10(3), 314-25.

Devroe, E. (2015a). Purple vests: The origins of plural policing in Belgium'. European Journal of Policing Studies, 2(3), 304-25.

Devroe, E. (2015b). Bringing politics back into the study of policing? A case-study on the policing of social disorder in Belgium. Policing and Society, 25, 4.

Devroe, E. (2016). Mind the gap: Over ASBOS and CRASBOS in Groot Brittannië, in T. Bauwens, S. Pleysier, E. De Pauw \& T. Van Den Broeck (eds), De nieuwe GAS-wet: zuurstof of stikstof? (pp. 47-58), Orde van de Dag, 73, Kluwer, Diegem.

Devroe, E. en Ponsaers, P. (2005). De discussie inzake (drug)overlast: enkele wetenschappelijke bevindingen. In: M. Santens (Ed.), Gewapend bestuur, Cohier tegenspraak, nr. 24, 141-159.

Devroe, E., \& Ponsaers, P. (2013). Reforming the Belgian police system between central and local'. In N. F. Fyfe, J. Terpstra, \& P. Tops (Eds.), Centralizing Forces? Comparative Perspectives on Contemporary Police Reform in Northern and Western Europe (pp. 77-98). The Hague: Boom Legal Publishers/Eleven.

Di Ronco, A., \& Peršak, N. (2014). 'Regulation of incivilities in the UK, Italy and Belgium: Courts as potential safeguards against legislative vagueness and excessive use of penal powers?' International Journal of Law. Crime and Justice, 42(4), 340-65.

Dupont, G. \& Ponsaers, P. (1988). Les Tueurs. Six Années d'Enquête, Anvers: EPO.

Edwards, A., \& Hughes, G. (2002). Introduction: The community governance of crime control'. In G. Hughes \& A. Edwards (Eds.), Crime Control and Community: The New Politics of Public Safety (pp. 1-19). Cullompton: Willan.

Edwards, A., \& Hughes, G. (2013). Comparative European criminology and the question of urban security'. European Journal of Criminology, 10(3), 257-9.

Edwards, A., Hughes, G., \& Lord, N. J. (2013). Urban security in Europe: Translating a concept in public criminology'. European Journal of Criminology, 10(3), 260-83.

Edwards, A., \& Prins, R. (2014). Policing and crime in contemporary London: A developmental agenda?'. European Journal of Policing Studies, 2(1), 61-93.

Feeley, M. M., \& Simon, J. (1992). The New Penology: Notes on the emerging strategy of corrections and its implications'. Criminology, 30(4), 449-74. 
Feeley, M. M., \& Simon, J. (1994). Actuarial justice: The emerging new criminal law'. In D. Nelken (Ed.), The Futures of Criminology (pp. 173-201). London: Sage.

Felson, M. (2002). Crime and everyday life. Londen: Sage publications. 211 p.

Field, F. (2003). Neighbours from Hell: The Politics of Behaviour. London: Politico's Publishing.

Fontana, A., \& Frey, J. (1994). Interviewing: The art of science'. In N. Denzin \& Y. Lincoln (Eds.), The Handbook of Qualitative Research (pp. 361-76). London/Thousand Oaks: Sage Publications.

Frevel, B. (2015). Pluralisation of local policing in Germany. European Journal of Policing Studies, 2(3), 26784.

Garland, D. (1997). The Punitive Society: Penology, Criminology and the history of the Present. Edinburgh Law Review, 1, 180-99.

Garland, D. (2001). The Culture of Control, Crime and Social Order in Contemporary Society. Oxford: Oxford University Press.

Garland, D. (2004). Beyond the culture of control. Critical Review of International Social and Political Philosophy, 7(2), 160-89.

Glorie, J. (1997). Ontstaan en ontwikkeling van de veiligheidscontracten'. In L. van Outrive \& S. Van Elchingen (Eds.), Veiligheidscontracten en Politie (pp. 5-10). Brussels: Politeia.

Glorie, J. (2004). De superministerraad van 30 en 31 maart 2004. Vigiles, 9(3), 73-5.

Goddard, T. (2012). Post-welfarist risk managers? Risk, crime prevention and the responsibilization of community-based organizations. Theoretical Criminology, 16(3), 347-63.

Hamilton, C. (2014). Reconceptualising Penality : A Comparative Perspective on Punitiveness in Ireland. Farmham, UK, Routlegde: Scotland and New Zealand.

Hope, T. (2000). Inequality and the clubbing of private security'. In T. Hope \& R. Sparks (Eds.), Crime, Risk and Insecurity: Law and Order in Everyday Life and Political Discourse (pp. 83-106). London: Routledge.

Hughes, G. (2007). The Politics of Crime and Community. London: Palgrave.

Huyse, L. (1996). De lange weg naar Neufchateau. Leuven: Van Halewyck.

Johnston, L., \& Shearing, C. (2003). Governing Security: Explorations in Policing and Justice. London/New York: Routledge.

Lijphart, A. (1999). Patterns of Democracy: Government Forms and Performance in Thirty-Six Countries. New Haven, CT: Yale University Press.

Mary, Ph. (1997). Le travail d'intérêt et la médiation pénale face à la crise de l'état social. Dépolitisation de la question criminelle et pénalisation du social, in $\mathrm{Ph}$. Mary (ed.), Le travail d'intérêt et la médiation pénale: Socialisation du pénal ou pénalisation du social? (pp. 325-47), Brussels: Bruylant.

Mary, P. (2005). Les figures du risque et de l'insécurité. L'impact sur le contrôle'. Informations Sociales, 126(6), $16-25$.

Matthews, R., Easton, H., Briggs, D., \& Pease, K. (2007). Assessing the Use and Impact of Anti-Social Behaviour Orders. Bristol: The Policy Press.

Mcara, L. (2005). Modelling penal transformation. Punishment and Society, 7(3), 277-302.

Melossi, D., \& Selmini, R. (2000). Social conflict and the microphysics of crime: The experience of the EmiliaRomagna Citta Secure project'. In T. Hope \& R. Sparks (Eds.), Crime, Risk and Insecurity: Law and Order in Everyday Life and Political Discourse (pp. 146-66). New York: Routledge.

Nelken, D. (2015). Foil comparison or foiled comparisons? Learning from Italian juvenile justice. European Journal of Criminology, 12(5), 519-34.

Newburn, T. et al. (2002). The introduction of referral orders into the Youth Justice System: final report, Home Office Research Study, 242 p.

O’Malley, P. (1999). Volatile and contradictory punishment'. Theoretical Criminology, 3(2), 175-96.

Orum, A. M., \& Feagin, J. R. (1991). A tale of two cases'. In J. R. Feagin, A. M. Orum, \& G. Sjoberg (Eds.), A Case for a Case Study (pp. 121-47). Chappell Hill: The University of North Carolina Press.

Osborne, D., \& Gaebler, T. (1993). Reinventing Government: How the Entrepreneurial Spirit is Transforming the Public Sector. New York: Plume.

Pratt, J., Brown, D., Brown, M., Hallsworth, S., \& Morrison, W. (Eds.). (2005). The New Punitiveness: Trends. Theories, Perspectives, Cullompton: Willan.

Radzinowicz, L. (1991). Penal regressions'. The Cambridge Law Journal, 50, 422-44.

Roché, S. (2005). Prevention and security: A new governance model for France through a contract based territorial approach'. Canadian Journal of Criminology and Criminal Justice, 47(2), 507-26.

Snacken, S. (2007). Penal policy and practice in Belgium. Crime and Justice, 36(1), 127-215.

Squires, P., \& Stephen, D. E. (2005). Rougher Justice: Anti-Social Behaviour and Young People. Cullompton: Willan.

Stone, C. N. (2008). Urban regimes and the capacity to govern: A political economy approach'. Journal of Urban Affairs, 15(1), 1-28. 
van Swaaningen, R. (1996). Justitie als verzekeringsmaatschappij: 'actuarial justice' in Nederland. JustitieleVerkenningen, 22, 80-7.

van Swaaningen, R. (2004). Veiligheid in Nederland en Europa; een sociologische beschouwing aan de hand van David Garland. Justitiële Verkenningen, 30(7), 9-23.

van Swaaningen, R. (2005). Public safety and the management of fear. Theoretical Criminology, 9(3), $289-305$.

Van Heddeghem, K. (2006). Bestuurlijke aanpak van overlast: de gemeentelijke administratieve sancties'. Panopticon, 27(2), 30-40.

Van Limbergen, M. (1995). Het veiligheidsbeleid in België’. Wijsgerig Perspectief, 36(3), 69-74.

Vander Beken, T. (2005). Minderjarigen en administratieve sancties'. In L. Veny \& N. D. de Vos (Eds.), Gemeentelijke administratieve sancties (plural policing (pp. 141-145). Bruges: Vanden Broele.

Vander Beken, T., \& Vandeviver, C. (2014). When things get serious: Reflections on the legitimacy of local administrative sanctions'. In N. Persak (Ed.), Legitimacy and Trust in Criminal Law, Policy and Justice: Norms, Procedures, Outcomes (pp. 35-49). Farnham: Ashgate.

Wacquant, L. (1998). La tentation pénale en Europe. Actes de la recherche en Sciences Socials, 124, 3-6.

Wacquant, L. (2004). Punir les pauvres. Le nouveau gouvernement de l'insécurité sociale, Marseille: Agone.

Willekens, P. (2008). Preventie: van project naar volwaardige schakel in de veiligheidsketen... Een proces van meer dan vijftien jaar. In K. Van Cauwenberghe (Ed.), De hervormingen bij politie en justitie: in gespreide dagorde, Jubileumeditie ter gelegenheid van tien jaar orde van de dag (pp. 289-301). Deventer: Kluwer.

Wilson, J., \& Kelling, G. (1989). Making Neighborhoods Safe. Atlantic Monthly, 263, 46-52.

Wodak, R. (2011). The Discourse of Politics in Action: Politics as Usual. Basingstoke: Palgrave Macmillan.

Young, J. (2007). The Vertigo of Late Modernity. London: Sage.

Young, J. (2009). Moral panic: Its origins in resistance, resentment and the translation of fantasy in to reality'. British Journal of Criminology, 49(1), 4-16.

Zedner, L. (2007). Preventive justice or pre punishment? The case of control orders'. Current Legal Problems, 60(1), 174-203. 